Külgazdaság, LXIV. évf., 2020. május-június (101-127. o.)

\title{
Globális válság, lokális likviditás? \\ A koronavírus-válság hatásának vizsgálata többországos DSGE-modell keretében likviditáskereslet alapján heterogén bankrendszerrel
}

CZELLENG ÁDÁM

A tanulmány a koronavírus-járvány által kiváltott válságot a bankrendszer likviditásának függvényében vizsgálta. Arra a kérdésre kereste a választ, hogy a bankrendszer likviditási helyzete az euróövezetben, illetve Magyarországon milyen módon és mértékben befolyásolja a pandémia által elöidézett gazdasági hatásokat. Az eredmények igazolják, hogy a pénzügyi frikciók (piaci súrlódások, tökéletlenségek) figyelembevételével - elsösorban a beruházásokra gyakorolt hatás mértéke miatt - a kilábalás üteme is eltérö lehet ahhoz képest, hogy a pénzügyi rendszer nem szerepel feltételként a modellben. A hatások erösebbek és a kilábalási pálya kismértékben módosul, ha a bankok likviditási poziciójuk alapján kerülnek megkülönböztetésre. A vizsgálati módszer egy több országot tartalmazó dinamikus modell volt. A cikk a hazai szakirodalomban elsöként dolgozta fel a bankrendszer likviditási pozíciójának hatásait gazdasági sokk esetén, megkülönböztetve a modellben likviditásbö és likviditáshiányos bankokat. Egyik következtetése, hogy a magyar bankrendszer likviditásának egyenletes bövitése - amelyben szerepe van mind a monetáris politikának, mind a szabályozásnak (mikro-és makroprudenciális politikának) - a hazai gazdaság stabilizálásának szükséges, de nem elégséges feltétele. A hatások aszimmetrikusak, azaz az euróövezet bankrendszere likviditásának javulása csak kismértékben járul hozzá a hazai hatás csökkentéséhez, de a negatív eredmény az euróövezetben szignifikánsan erösíti a negatív hazai makrogazdasági

A kézirat első változata 2020. április 16-án érkezett szerkesztőségünkbe.

https://doi.org/10.47630/KULG.2020.64.5-6.101

Czelleng Ádám, GKI Gazdaságkutató Zrt., illetve Budapesti Gazdasági Egyetem Külkereskedelmi Kar. E-mail: czelleng.adam@uni-bge.hu

A szerző köszönettel tartozik anonim lektorainak, akiknek a véleménye nagymértékben hozzájárult a tanulmány színvonalának javításához. 
hatásokat. A hatások minimalizálásához szükségesek célzott, jól időzitett intézkedések, amelyek átlátható és fenntartható (minimális prudenciális elvárásoknak eleget tevö) tevékenység mellett segithetik a kilábalást.

Journal of Economic Literature (JEL) kódok: E12, F37, G21, G28.

Kulcsszavak: többországos DSGE, monetáris politika, likviditás, szabályozás.

\section{Bevezetés}

A 2019 végén kirobbant, majd 2020 elejétől fokozatosan az egész világra kiterjedő koronavírus-járvány súlyos gazdasági következményekkel jár. A gazdasági hatások elsősorban a vírus terjedésének megakadályozását célzó szigorú korlátozásokkal kapcsolatosak, amelyek lazításának ideje, módja és mértéke még csak körvonalazódik.

A mostani epidemiológiai hátterủ krízistől eltérően a 2008-2009. évi nemzetközi pénzügyi és gazdasági válság pénzügyi okokkal volt magyarázható. Az azóta bevezetett likviditási és tőkeszabályok nagymértékben javították a pénzügyi rendszer stabilitását. A 2010-es évek elejétől nagyszámú tanulmány elemezte a szabályozás makrogazdasági hatásait és költségeit (többek között Fender-Lewrick, 2016; Eickmeier et al., 2018; Cozzi et al., 2020). Egyes tanulmányok több makromodell alapján arra a következtetésre jutottak, hogy 1 százalékos tökekövetelmény-emelés 0,15-0,35 százalékkal mérsékeli a GDP növekedési ütemét rövid távon. Hatékonyabb monetáris transzmisszió mellett azonban a hatás 0,05-0,15 százalékra mérséklődik.

A jelenlegi válsághelyzetben is fontos szerepe van a bankrendszernek. Amíg a likviditási elégtelenségek számottevő másodkörös negatív hatást eredményezhetnek, addig a bankrendszer forrásnyújtása segítheti a gazdaságok gyors visszarendeződését.

A tanulmányban arra a kérdésre kerestem a választ, hogy a bankrendszer likviditási helyzete milyen módon és mértékben befolyásolja a koronavírus-járvány által elöidézett gazdasági hatásokat az euróövezetben, illetve Magyarországon. A vizsgálati módszer egy többországos dinamikus modell, amely heterogén bankokat különböztet meg, így a bankközi piacnak és likviditásának megkerülhetetlen szerepe van a gazdasági sokkokra adott reakciókban. A tanulmány Magyarországra koncentrál. A koronavírus-járvány többkörös és több csatornán át gyürüző hatásai miatt a problémát egy több országot tartalmazó dinamikus sztochasztikus általános egyensúlyi modellben elemeztük. A modellt az euróövezetre és Magyarországra kalibráltuk. 
A tanulmány a hazai és a nemzetközi szakirodalomban elsőként dolgozta fel egy kis és nyitott országot, illetve nagy gazdasági egységet tartalmazó dinamikus modellben a nemzetközi tőkeáramlások figyelembevételével a gazdasági sokkok és a heterogén szereplőkből álló bankrendszer likviditási pozíciója közötti összefüggéseket, hatásokat, hatásmechanizmusokat és következményeket. Az elemzésben tekintettel voltunk a bankközi piaci kondíciókra, a nemzetközi tőkeáramlásra és a dinamikusan optimalizáló gazdasági aktorokra. Szem előtt tartva a bankrendszer heterogenitását, jelen vizsgálat segíthet megérteni a monetáris politika és a szabályozás közötti átfedést, beleértve ennek jelentőségét a makrogazdasági fenntarthatóság szempontjából. A likviditás vizsgálatának relevanciáját az a tény adja, hogy a bankrendszer likviditásbősége esetén is megkülönböztethetők likviditásszufficites és likviditásdeficites bankok. Ezek a pozíciók az egyes bankok szintjén a tranzakciók függvényében naponta is változhatnak. A bankok likviditástöbbletük vagy -hiányuk alapján hatnak a piaci keresletre.

A tanulmány első része a főbb hatásokat és hatásmechanizmusokat tekinti át a szakirodalmi források alapján. A második rész az alkalmazott modellt mutatja be, a harmadik az eredményeket közli. A negyedik rész értékeli a kapott eredményeket, az ötödik az összefoglalást és a következtetéseket tartalmazza.

\section{Hatások és hatásmechanizmusok a szakirodalmi források alapján}

A szakirodalom likviditáson a kötelezettségek időbeli teljesítését, a forrásokhoz való hozzáférhetőséget, a pénzügyi eszközökkel való kereskedés akadálymentességét és költségszintjét, valamint a gazdaságban elérhető szabad pénzeszközök mennyiségét érti. A likviditás e dimenziói egymással szorosan összefüggnek, kölcsönösen hatnak egymásra (Váradi, 2012). Például a piaci likviditás bővülésével kedvezőbbé válhat a bankrendszer likviditási pozíciója is, mert a bankok könnyebben tudják értékesíteni pénzügyi eszközeiket, és ezáltal könnyebben juthatnak piaci forráshoz. Ugyanakkor a bankok nagyobb piaci aktivitása révén a bankrendszer likviditásának javulása elősegítheti a piaci likviditás bővülését is. Az empirikus eredmények ez utóbbi kapcsolatot igazolták nagyobb mértékben (Adrian-Shin, 2009; Jylha, 2016).

A bankközi piac a jegybankpénz piaca, amelynek kínálatát a jegybank monopolhelyzetből biztosítja, keresletét pedig a bankok generálják. Természetéből adódóan a pénzügyi közvetítőrendszer rövid lejáratú forrásokból hosszú távú eszközöket finanszíroz, így a szolvens bankoknak is refinanszírozniuk kell eszközeiket, ennek 
révén jegybankpénz iránti keresletet hoznak létre. A bankok esetében ezt likviditási keresletnek nevezzük. Egyrészt az ügyfelek készpénzigényének kielégítése miatt folyamatosan likviditáskeresletet teremtenek, másrészt likviditástöbbletük vagy -hiányuk alapján hatnak a piaci keresletre. A többletek és a hiányok a bankok fizetési és elszámolási rendszereinek nettó pozíciója függvényében alakulnak, ami a napi müködés során végrehajtott tranzakciókból adódik. Harmadrészt, a jegybank kötelező tartalékrátája is hatással van a bankok likviditási keresletére.

A 2008-2009. évi nemzetközi pénzügyi és gazdasági válság után a világ vezető jegybankjai a gazdasági visszaesés mérséklése és a pénzügyi piacok hatékony müködésének elősegítése érdekében a végső hitelezői pozíció ellátása mellett egyes lejáratokon vállalták, hogy bővítik a hozambefolyásoló szerepet. A rövid lejáratok mellett a hosszabbakon is alacsonyan próbálják tartani a hozamokat, ezzel javítják a monetáris transzmisszió hatékonyságát és biztosítják a piaci likviditást. A pénzügyi piacok likviditásának magas szintje teszi lehetővé az információk hatékony allokációját és a hatékony portfólióképzést. A többletpénzmennyiség, valamint a mérsékelt likviditási kockázat csökkenti a befektetők, illetve beruházók forráshoz jutási költségét. Ez összességében magasabb keresletet indukál, ezáltal inflációt gerjeszt. A jegybankok által biztosított többletlikviditás lehetőséget nyújthat olyan beruházási projektek megvalósítására is, amelyekre a növekvő kockázatkerülés miatt receszszió idején nem kerülne sor (akár banki, akár közvetlen pénzügyi piaci forrásokra támaszkodva).

A mennyiségi és a minőségi lazítás formáját öltő likviditásbővítési programok ugyanakkor - amellett, hogy kockázatokat is rejtenek magukban - befolyásolják a gazdaságpolitikai eszközök hatékonyságát is. A programok bevezetésére többnyire akkor kerül sor, amikor a konvencionális eszközök elérik effektív határukat. A bankrendszer likviditásbősége általában véve csökkenti a monetáris politika hatékonyságát. Likviditásban bővelkedő bankrendszer esetén a monetáris politika passzív oldalról tud beavatkozni, így hat a bankrendszer marginális hozamára. A likviditáshiányos bankrendszer esetében a jegybankok aktívan, azaz nettó hitelezőként képesek kezelni a likviditást, így a bankrendszer marginális forrásköltségén keresztül hatékonyabban képesek elérni kitüzött céljaikat. Természetesen ez hatással van a fiskális politikára is, mert csökken a forrásbevonás költsége - ami ösztönözheti a költségvetési politika lazítását is, egyrészt lehetővé teszi a strukturális problémák kezelését, másrészt utat nyithat a fiskális felelőtlenség előtt.

A jegybanki programok révén a bankrendszerbe juttatott addicionális likviditás szükségképpen a jegybanknál vezetett számlákon marad, mivel az egyedi ban- 
kok képesek értékesíteni az általuk többletnek ítélt likviditást, de az szükségszerüen egy másik bankhoz kerül. Összességében a bankrendszer likviditásbősége esetén is megállapítható, hogy a bankok heterogenitása miatt megkülönböztethetők likviditásszufficites és likviditásdeficites bankok.

Kolozsi és Horváth [2020] a 2016 és 2019 közötti időszakon vizsgálták a magyar bankrendszer likviditáskeresleti függvényét. A jegybank által a piacra juttatott 410 milliárd forintnyi többletlikviditás lehet a magyar bankrendszer szaturációs pontja. Jelen tanulmány számára fontos megállapítás, hogy a likviditás bővítése kiegyenlítettebbé teszi annak eloszlását, így csökkenti a bankközi piac forgalmát.

A tanulmányban azt feltételezem, hogy likviditáshiányosak azok a bankok, amelyek a napi tranzakciók eredményeként tartósan likviditásdeficittel rendelkeznek, illetve amelyek a napi tranzakciók eredményeként nem felelnének meg az MNB felügyelete által támasztott likviditási követelményeknek.

A koronavírus-járvány miatt kieső jövedelmek eredményeként a példátlan mértékủ közvetlen gazdasági hatásokat jelentős másodkörös hatások követik. Kritikus kérdés, mennyire sikerül minimalizálni a gazdasági szereplők jövedelemkiesését és a munkaerő elbocsátását, hogy a kereslet zuhanása ne okozzon hosszú távú strukturális gondokat. Kritikus kérdés az is, hogy az egyes gazdaságok mennyire tudják megtartani a kínálati kapacitásokat, azok alakulása hogyan hat a hosszú távú potenciális növekedési pályára, és milyen mértékủ a recesszió, azaz mennyire szélesedik a kibocsátási rés.

Rövid távon ez természetesen erős dezinflációs, illetve deflációs nyomás alá helyezi a gazdaságokat és növeli a jövedelemegyenlőtlenséget. Mindez már középtávon is visszafogja a gazdasági teljesítményt, fokozza az instabilitást, hosszú távon pedig jelentős versenyképesség-romláshoz vezethet, ha az egyéneket korlátozza tehetségük kiaknázásában.

Az előbbiek tudatában a kormányok és a jegybankok nagyon gyorsan cselekedtek. A 2008-2009. évi nemzetközi pénzügyi és gazdasági válság (akkoriban „egyszer az életben” válságként emlegetett visszaesés) még élénken él a szakértők és a politikusok emlékezetében. Az eszköztár jó része már kipróbált, így gyorsan alkalmazták is a gazdaságpolitikai döntéshozók: költségvetési expanzió a fiskális, mennyiségi lazítás a monetáris politikában. Ugyanakkor olyan új eszközök is megjelentek, amelyek jelentős mértékben és hosszú távon is megváltoztathatják az állam gazdaságban betöltött szerepét. Néhány kormány közvetlen bértámogatást, extra juttatásokat, illetve alapjövedelmet biztosít (egyelőre) átmenetileg a munkavállalóknak, 
illetve a munkanélkülieknek. A jegybankok annyi likviditást adnak a gazdaságnak, hogy a fiskális expanzió költségei a lehető legalacsonyabbak legyenek.

A 2008-2009. évi nemzetközi pénzügyi és gazdasági válság után a nemkonvencionális monetáris politikai eszközök terjedésével elötérbe került a pénzügyi frikciók hatásainak modellezése. Az első nagy hatású tanulmányok egyike, amely pénzügyi súrlódásokkal is foglalkozott, Bernanke, Gertler és Gilchrist [1998] írása. A szerzők modelljükben endogenizálták a hitelpiacot, ami lehetővé tette annak elemzését, hogy a különböző makrogazdasági sokkok terjedését hogyan segíti a pénzügyi akcelerátor, illetve a hitelpiaci súrlódások hogyan befolyásolják a monetáris politika transzmissziós mechanizmusának hatékonyságát.

Iacoviello [2005], valamint Gerali és szerzötársai [2010] modelljeikben nem tökéletesen versenyző bankokat és endogén tőkeakkumulációt feltételeztek. A bankok forrást vonhatnak be a lakossági betétek és a bankközi hitelek felhasználásával. Eredményeik szerint a banki tőkekövetelmények befolyásolják a makrogazdasági sokkokra adott válaszokat.

Gertler és Karádi [2011] tanulmánya új szemszögből közelítette meg a pénzügyi rendszer makrogazdasági súrlódásait. Modelljükben endogenizálták a pénzügyi intézmények és a megtakarítók közötti ügynökproblémát, ami mérlegkorlátokon keresztül befolyásolja a bankok optimalizáló magatartását. Ez elsőként tette lehetővé a mennyiségi lazítás makrogazdasági hatásainak vizsgálatát, beleértve annak optimális szintjét és a társadalom számára biztosított jóléti nyereséget.

Többországos DSGE-modelleket elsősorban nemzetközi intézmények használnak előrejelzéseikhez (Európai Bizottság, 2017; Carabenciov et al., 2008). Ez a tanulmány a nemzetközi tőkeáramlás és a bankközi piaci kapcsolatok - Poutineau és Vermandel [2014] által bemutatott - modelljére támaszkodik, amellyel a határokon átnyúló pénzügyi kapcsolatok makrogazdasági hatásait vizsgálták. Mivel az eredeti modellben csak az euróövezet országai szerepeltek, ezért Magyarország és az euróövezet kapcsolatának elemzéséhez szükség volt a modell módositására és kibővitésére.

\section{A modell}

A modellben két gazdasági egység szerepel: az euróövezet és Magyarország. A modell bemutatásánál annak főbb jellemzőire fókuszálunk, a részletes leírás letölthető a szerző személyes oldaláról (https://czellengadam.wixsite.com/home). Mind a két entitás esetében háztartási, vállalati és banki reprezentatív szereplőket definiáltunk. 
A modellben szereplö reprezentatív háztartások hasznosságuk maximalizálása révén határozzák meg döntéseiket, így Gali [2007] alapján döntenek fogyasztásukról, megtakarításukról és munkakínálatukról. A két háztartás (az euróövezetben és Magyarországon) az alábbiakban bemutatott hasznossági függvénnyel rendelkezik.

Háztartások

$$
\max _{\left\{C_{i, t}(j), H_{i, t}(j), B_{i, t+1}(j)\right\}} E_{t} \sum_{\tau=0}^{\infty} \beta^{\tau} e^{\varepsilon_{i, t+\tau}^{\beta}}\left[\frac{\left(C_{i, t}(j)-h_{i}^{c} C_{i, t-1+\tau}\right)^{1-\sigma_{i}^{c}}}{1-\sigma_{i}^{c}}-X_{i} \frac{L_{i, t+\tau}^{1+\sigma_{i}^{L}}(j)}{1+\sigma_{i}^{L}}\right],
$$

ahol $C$ a fogyasztást, $L$ pedig a munkaórákat jelöli. A hasznossági függvény korlátja a háztartások költségvetési korlátja, ami az alábbi:

$\frac{W_{i, t}^{h}}{P_{i, t}^{c}} L_{i, t}(j)+R_{t-1} \frac{B_{i, t}(j)}{P_{i, t}^{c}}+\frac{\Pi_{i, t}(j)}{P_{i, t}^{c}}+\left(1+R^{*}{ }_{t-1}\right) S_{t} N F A_{t-1}=C_{i, t}(j)+\frac{B_{i, t+1}(j)}{P_{i, t}^{c}}+\frac{T_{i, t}(j)}{P_{i, t}^{c}}+S_{t} N F A_{t}$

ahol bevételi oldalon a bér, a hazai és a külföldi kötvények utáni kamatfizetés és a vállalati profit (mivel a vállalatok végső soron a háztartások tulajdonában vannak) áll. A kiadási oldalt a fogyasztás, a hazai és a külföldi kötvényvásárlás és az adók képezik. A magyar háztartások esetében a hasznossági függvény egy további lépést is tartalmaz, ami meghatározza a hazai és az importált fogyasztási termék arányát.

Vállalatok

A vállalati szektor esetében kétszintű termelést feltételezünk. A vállalatok tőkeés munkaerőigényüket határozzák meg, és az elérhető technológia mellett CobbDouglas-típusú termelési függvénnyel termelnek:

$$
Y_{i, t}(i)=A K_{t}^{\alpha} L_{t}^{1-\alpha}
$$

A döntési folyamat során a vállalat maximalizálni kívánja profitját, amelyet a tőke és a munkaerő költsége $(W)$ nyomán kíván optimalizálni. Ennek lapján az alábbi határköltség-egyenletet kapjuk:

$$
M C_{i, t}(i)=M C_{i, t}=\frac{1}{A}\left(\frac{I N T_{i, t}}{\alpha}\right)^{\alpha}\left(\frac{W_{i, t}}{(1-\alpha)}\right)^{1-\alpha}
$$


Beruházások

A bankokat, a bankok likviditását és a bankközi piacot Poutineau és Vermandel [2014] modellje alapján vizsgáltuk, amely a centrum és a periféria országai közötti tőkeáramlást vette alapul. Modelljükben az euróövezethez tartozik mindkét vizsgált régió, így a közös monetáris politika hat a monetáris kondíciókra. A reálgazdasági folyamatok is kölcsönösen hatnak egymásra. Az ebben a tanulmányban vizsgált kérdések esetében ugyanakkor ezek a feltevések nem érvényesek, így az átalakított és kibővített modellt az alábbiakban mutatjuk be.

A bankok tökéletes versenyző szereplők, amelyek tőkét bocsátanak a gazdaság rendelkezésére.

A beruházási egyenletet az alábbi módon vezettük le:

$$
I_{i, t}(k)=\left(\left(1-\alpha_{i}^{I}\right)^{1 / \mu} I_{E U, i, t}(k)^{(\mu-1 / \mu)}+\left(\alpha_{i}^{I}\right)^{1 / \mu} I_{H U, i, t}(k)^{(\mu-1 / \mu)}\right)^{\mu /(\mu-1)},
$$

ahol $\mu$ a helyettesítési paraméter a két entitás beruházási javai között, az $\alpha_{i}^{I}$ paraméter pedig a beruházási javak diverzifikációjának szintjét határozza meg. Az euróövezet esetében az $\alpha_{i}^{I}$ paraméter 0 , azaz a beruházások kizárólag az euróövezet beruházási javaira támaszkodnak.

A tőkeberuházásokat a bankrendszer vállalati hitelnyújtás révén finanszírozza. Likviditási pozíciója és a beruházási kereslet függvényében a bankrendszer bankközi hiteleket is nyújt. A modellben végzett módosítások miatt az euróövezet hitelkereslete nem érinti közvetlenül a magyar piacot. A hatás ugyanakkor közvetetten jelentkezik, azaz a likviditás csökkenése miatt a magyar bankrendszer drágábban juthat forráshoz.

A bankrendszer leírása során megkülönböztetünk likvid és illikvid bankokat. Az illikvid bankok hitelezési korláttal szembesülnek, és hitelt kapnak a likvid bankoktól, hogy hitelt nyújthassanak a beruházások finanszírozásához:

$$
H_{i, t+1}^{\text {s,llikvid }}(b)=B K_{i, t+1}^{H}(b)+B T^{\text {illikvid }}{ }_{i, t+1}(b)+\text { kötelezettség }_{i l t i k v i d}^{\text {ill }}(b),
$$

ahol $H_{i, t+1}^{\text {sillikvid }}(b)$ az illikvid bank hitelkínálata, $B K_{i, t+1}^{H}(b)$ a likvid bankoktól kapott bankközi hitel, $B T^{\text {illikvid }}{ }_{i, t+1}(b)$ a bank tőkéje és a kötelezettség ${ }_{i, t}^{\text {illikvid }}(b)$ a bank kötelezettsége. 
A beruházók nem veszik figyelembe, hogy a bank likvid vagy sem, ugyanakkor a bankok csődvárakozásai meghatározzák az elvárt hozamot. A csődvárakozásokat modellünkben az alábbi egyenlet ragadja meg:

$$
\eta_{i, t+1} \equiv\left(1-\alpha_{i}^{L}\right) \eta_{E U, t+1}{ }^{E}+\alpha_{i}^{L} \eta_{H U, t+1}{ }^{E},
$$

ahol $\eta_{t+1}{ }^{E}$ az euróövezetben, illetve Magyarországon jellemző csődráta, míg az $\alpha_{i}^{L}$ a vállalati hitelek diverzifikációját képviselö paraméter a két ország között.

Az illikvid bank bankközi hitelkeresletét az alábbi egyenlet mutatja meg:

$$
B K_{i, t+1}^{i l l i k v i d}(b)=\left(\left(1-\alpha_{i}^{B K}\right)^{1 / \xi} B K_{E U, i, t+1}^{d}(b)^{(\xi-1 / \xi)}+\left(\alpha_{i}^{B K}\right)^{1 / \xi} B K_{H U, i, t+1}^{d}(b)^{(\xi-1 / \xi)}\right)^{\xi /(\xi-1)} .
$$

A likvid bankok saját forrásból képesek fenntartani hitelezésüket, továbbá bankközi hiteleket (BK) nyújtanak az illikvid bankoknak:

$$
H_{i, t+1}^{l i k v i d}(b)+B K_{i, t+1}^{l i k v i d}(b)=B T_{i, t+1}(b)+\text { kötelezettsé } g_{i, t}(b) .
$$

A bankközi kamatlábakat az alábbi egyenlet határozza meg:

$$
R_{i, t}^{I B}(b)=\chi_{i}^{I B}\left(B K_{i, t+1}(b)-\overline{B K_{l}^{s}}(b)\right)+R_{t},
$$

ahol $B K_{i, t+1}(b)$ a bankközi piacon szerződött összeg a $t$ időszakban, míg $\overline{B K_{l}^{s}}(b)$ az egyensúlyi állapothoz tartozó bankközi hitelek állománya.

A beruházásokhoz a beruházási javakat gyártó vállalatok saját vagyonukat és hitelt használnak fel, a hitelt az euróövezeti beruházók az euróövezet bankjaitól, míg a magyar vállalatok elsősorban magyar bankoktól, de az euróövezet bankjaitól is felvehetik. A hitelek nagyságát az alábbi egyenlet határozza meg:

$$
H_{i, t+1}(e)=Q_{i, t} K_{i, t+1}(e)-N_{i, t+1}(e) .
$$

A hazai és a külföldi hitel közötti megoszlást CES-típusú függvénnyel határoztuk meg:

$$
H_{i, t+1}^{d}(e)=\left(\left(1-\alpha_{i}^{H}\right)^{1 / v} H_{H U, i, t+1}^{d}(e)^{(v-1) / v}+\left(\alpha_{i}^{H}\right)^{1 / v} H_{E U, i, t+1}^{d}(e)^{(\nu-1) / v}\right)^{v /(v-1)},
$$

ahol $v$ a helyettesíthetőségi paraméter, míg $\alpha_{i}^{H}$ a nemzetközi hitelek arányát jeleníti meg. 
A Taylor-szabály szerint a monetáris politika meghatározza a nominális kamatlábszintet. Az euróövezet esetében az inflációs és a növekedési cél a célfüggvény paramétere, míg a magyar monetáris politika esetében az euróövezeti inflációs hatás is szerepel a döntési folyamatban.

Az árfolyamot a fedezetlen kamatparitás elve alapján határozzuk meg.

\section{Eredmények}

A koronavírus-járvány hatására a magyar gazdaságot több körben érik a különböző sokkok. Első körben a sokk a globális ellátási láncokon keresztül jelentkezik, elvágva a termelőkapacitásokat a szükséges alapanyagoktól, félkész termékektől és egyéb termelési inputoktól, ezzel ellehetetlenítve a termelést.

A második körben a külső piacokat éri keresleti sokk, azaz a magyar gazdaság számára fontos felvevőpiacokon jelentős mértékben csökken a kereslet, ami nehéz helyzetbe hozza a hazai exportőröket.

A harmadik körben pedig az emberek közötti személyes kapcsolatok korlátozása miatt termeléskiesésre kerül sor, ami a jövedelem- és bevételkiesés következtében nehezíti a hazai termelők és háztartások helyzetét. Ez alapján a modellben alkalmazott sokkok az alábbiak:

A modellben alkalmazott sokkok

\begin{tabular}{lc}
\hline Sokkok & Paraméter \\
\hline Külpiaci lakossági preferencia & $\beta^{E U}$ \\
Külpiaci eszközárak & $Q^{E U}$ \\
Külpiaci munkaórák & $L^{H U}$ \\
Hazai lakossági preferencia & $\beta^{H U}$ \\
Hazai eszközárak & $Q^{H U}$ \\
Hazai prémium & Prem \\
Hazai munkaórák & $L^{H U}$ \\
\hline
\end{tabular}


Az egyes hatások mértékében és tartósságában olyan mértékủ a bizonytalanság, amire korábban nem volt példa. A jelenlegi környezet leginkább egy természeti katasztrófához hasonlítható, amely nem csak lokálisan fejti ki hatásait. Az egyes országok esetében érezhető hatások függnek a helyi gazdaságot érintő korlátozások mértékétől, a gazdaság szerkezetétől, a gazdaságpolitikai intézkedésektől, valamint a gazdasági kapcsolatok miatt fontos országokat érintő hatásoktól. Emiatt a Magyarországról 2020-ra készített elörejelzések rendkívül széles skálán mozognak. Ezt mutatja az 2. táblázat, amely a hazai kutatóintézetek, a Magyar Nemzeti Bank, az Európai Bizottság és a Nemzetközi Valutaalap prognózisait foglalja össze.

2. táblázat

\section{Magyarországról készített prognózisok 2020-ra, az egyes kutatóintézetek által publikált előrejelzések alapján}

\begin{tabular}{|c|c|c|}
\hline Kutatóintézet & $\begin{array}{l}\text { Magyarországra vonatkozó } \\
\text { GDP-prognózis 2020-ra }\end{array}$ & Föbb hatások \\
\hline GKI Gazdaságkutató(1) $^{(1)}$ & $\begin{array}{l}-3 \text { és }-7 \% \text { közötti visszaesés } \\
\text { a feltételek változásának } \\
\text { függvényében }\end{array}$ & $\begin{array}{l}\text { - Lakossági korlátozások } \\
\text { - Romló várakozások } \\
\text { - Csökkenő beruházások } \\
\text { - Turizmus, szállítás, pénzügyi szektor a } \\
\text { vesztesek között }\end{array}$ \\
\hline Európai Bizottság ${ }^{(2)}$ & $-7 \%$ & $\begin{array}{l}\text { - „V” alakú válság (jelentős válság, } \\
\text { jelentős visszapattanás 2021-ben) }\end{array}$ \\
\hline Kopint-Tárki Zrt. ${ }^{(3)}$ & $\begin{array}{l}-5,5 \% \text { (a korlátozások } \\
\text { elhúzódása esetén akár }-10 \% \\
\text { körüli visszaesés) }\end{array}$ & $\begin{array}{l}\text { - Keresleti sokk: magánfogyasztás és } \\
\text { beruházások } \\
\text { - Kínálati sokk: csökkenő munkaórák, } \\
\text { leálló ágazatok }\end{array}$ \\
\hline Magyar Nemzeti Bank ${ }^{(4)}$ & $\begin{array}{l}+2 \text { és }+3 \% \text { közötti gazdasági } \\
\text { növekedés }\end{array}$ & $\begin{array}{l}\text { - Második negyedévben csökkenés, } \\
\text { majd visszarendeződés („V” alakú } \\
\text { válság) } \\
\text { - Leginkább kitett ágazatok egyhavi } \\
\text { leállása (jármügyártás, turizmus, szál- } \\
\text { lítmányozás, kulturális szolgáltatások) }\end{array}$ \\
\hline Nemzetközi Valutaalap ${ }^{(5)}$ & $-3 \%$ & $\begin{array}{l}\text { - A szükséges korlátozások jelentős visz- } \\
\text { szaesést eredményeznek, de segítenek } \\
\text { fenntartani a hosszú távú növekedési } \\
\text { potenciált } \\
\text { - „V” alakú válság }\end{array}$ \\
\hline
\end{tabular}




\begin{tabular}{l|l|l}
\hline Kutatóintézet & $\begin{array}{l}\text { Magyarországra vonatkozó } \\
\text { GDP-prognózis 2020-ra }\end{array}$ & Főbb hatások \\
\hline $\begin{array}{l}\text { Századvég } \\
\text { Gazdaságkutató Zrt.(6) }\end{array}$ & $\begin{array}{l}-0,3 \text { és }-4,8 \% \text { közötti vissza- } \\
\text { esés a feltételek változásának } \\
\text { függvényében }\end{array}$ \\
\hline
\end{tabular}

(1) 2020. 3. 23-án publikált.

(2) 2020. 5. 6-án publikált.

(3) 2020. 4. 10-én lezárt prognózis.

(4) 2020. 4. 7-én publikált Inflációs jelentés alapján.

(5) 2020. 4. 14-én publikált.

(6) 2020. 3. 25-én publikált negyedéves elörejelzés alapján.

Forrás: Saját szerkesztés a kutatóintézetek és nemzetközi intézmények által közölt prognózisok alapján. Kutatóintézetek (2020), European Commission (2020), International Monetary Fund (2020).

A sokkokat a modellben annak megfelelően súlyoztuk, hogy az IMF előrejelzése $^{1}$ szerinti GDP-reakciókat kapjuk. Ez alapján az euróövezet esetében 7,5 százalékos, míg a magyar gazdaság esetében - optimistának tűnö ${ }^{2}-3$ százalékos recesszióval számoltunk 2020-ban.

3. táblázat

Az euróövezet GDP-jéhez való hozzájárulás és az IMF 2020-ra vonatkozó prognózisa

\begin{tabular}{l|c|c}
\hline Ország & Euróövezeten belüli részesedés 2018-ban (\%) & IMF-prognózis 2020-ra (\%) \\
\hline Belgium & 4,0 & $-6,9$ \\
Németország & 28,9 & -7 \\
Észtország & 0,2 & $-7,5$ \\
Írország & 2,9 & $-6,8$ \\
Görögország & 1,6 & -10 \\
Spanyolország & 10,5 & -8 \\
Franciaország & 20,3 & $-7,2$ \\
Olaszország & 15,0 & $-9,1$ \\
Ciprus & 0,2 & $-6,5$ \\
Lettország & 0,3 & $-8,6$ \\
\hline
\end{tabular}

${ }^{2}$ Az Európai Bizottság 7 százalékos recessziót vetített elöre Magyarország számára. 
Globális válság, lokális likviditás?

\begin{tabular}{l|c|c}
\hline Ország & Euróövezeten belüli részesedés 2018-ban (\%) & IMF-prognózis 2020-ra (\%) \\
\hline Litvánia & 0,4 & $-8,1$ \\
Luxemburg & 0,5 & $-4,9$ \\
Málta & 0,1 & $-2,8$ \\
Holland & 6,8 & $-7,5$ \\
Ausztria & 3,3 & -7 \\
Portugál & 1,8 & -8 \\
Szlovénia & 0,4 & -8 \\
Szlovákia & 0,8 & $-6,2$ \\
Finnország & 2,0 & -6 \\
\hline
\end{tabular}

Forrás: Eurostat és IMF adatbázis.

A benchmarkeredmények alapján a kalibráláshoz a 4. táblázatban található empirikus értékeket használtuk.

4. táblázat

\section{A modell kalibrációjának fóbb paraméterei}

\begin{tabular}{lcc}
\hline & Euróövezet & Magyarország \\
\hline A termelés tőkeintenzitása & 0,3 & 0,4 \\
A fogyasztás aránya a GDP-ben (\%) & 66,3 & 58,8 \\
A beruházások aránya a GDP-ben (\%) & 21,1 & 23,6 \\
A nettó export aránya a GDP-ben (\%) & 2,8 & 3,1 \\
\hline
\end{tabular}

Forrás: Eurostat adatai alapján saját számítás. 


\section{Impulzus-válaszfüggvények a koronavírus hatásairól az IMF várakozásait tükröző sokk esetén}

(Minden változó százalékos változása)
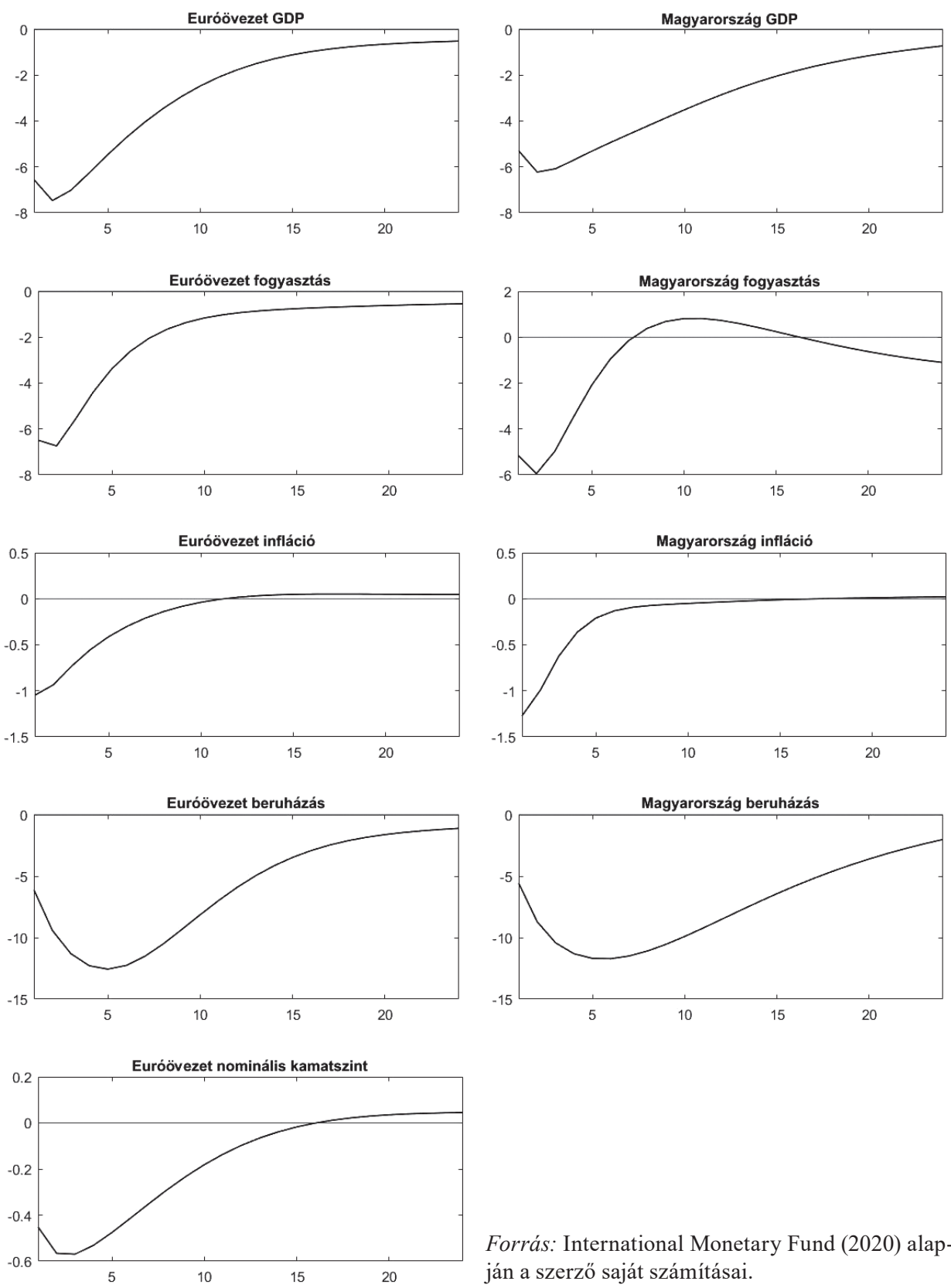

Forrás: International Monetary Fund (2020) alapján a szerző saját számításai. 
2. ábra

Impulzus-válaszfüggvények a koronavírus hatásairól az IMF várakozásait tükröző sokk esetén

(Minden változó százalékos változása)
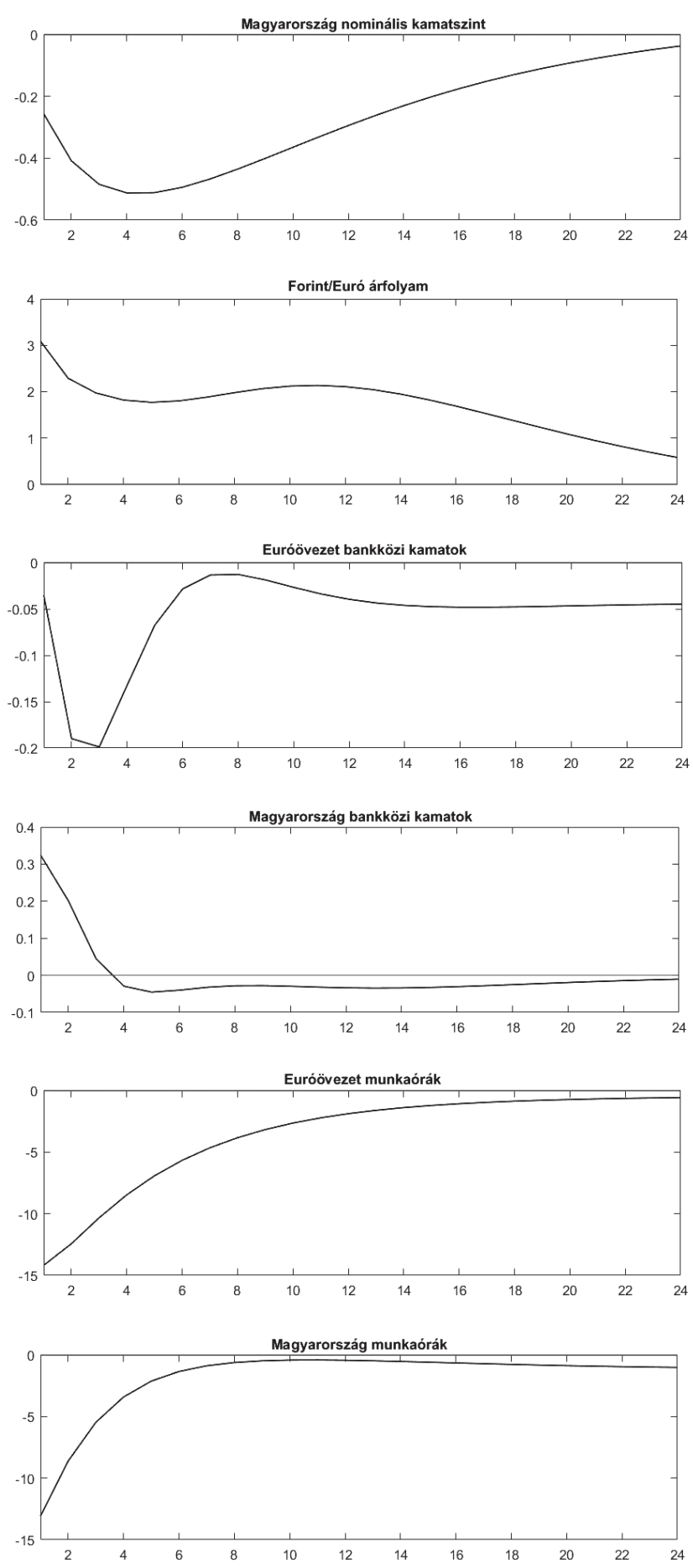

Forrás: International

Monetary Fund (2020) alapján a szerző saját számításai. 
A benchmarkszcenárió eredményei a GDP tekintetében az IMF várakozásait tükrözik - mivel ez alapján állítottuk be a sokkok nagyságát -, azaz a GDP-hatás 5-6 százalék közötti Magyarországon (amelyet a korábbi 3 százalékos növekedési várakozásokra vetítve 3 százalékos recesszió jelez). Az euróövezet esetében 7,5 százalék körüli GDP-hatást várhatunk egy amúgy is stagnáló gazdaságban. A beruházásokra gyakorolt hatások kicsit elnyújtva jelentkeznek ugyan, de a legszignifikánsabbak. Mindkét modellezett gazdasági egységben 10 százalékot is meghaladó visszaesés várható a magánberuházásokban. A magánfogyasztás ettől némileg eltérő lefutással és mérsékeltebb hatással reagál. A csökkenő kereslet nyomán mérséklődik az infláció, a gazdaságban dezinflációs, illetve deflációs nyomás jelentkezik. A gazdasági hatásokat számításba véve a modell az euróövezetben 60 bázispontos, Magyarországon 50 bázispontos lazítást javasol a monetáris kondíciókban.

A bankközi piacokat tekintve az euróövezetben csökken a bankközi kamatláb, majd gyors növekedés (egyensúlyi pályára való visszaállás) várható, míg a magyar bankközi piacon emelkedés, majd mérséklődés (korábbi szint visszaállása) valószínüsíthető. Az empirikus adatok is erre utalnak. A válság kitörése óta az euróövezetben a bankközi piacon a kamatlábak „V” alakú mintát mutatva a reakció után gyorsan növekedtek, míg a magyar bankközi piacokon folyamatos emelkedés tapasztalható, ami egybevág a modell alapján várt reakciókkal. A sokk hatására a nominális árfolyam ugrásszerủ leértékelődése volt tapasztalható, ezért hosszú távon folyamatos leértékelődés várható.

A sokkok mértékét megtartva azok hatását vizsgáltuk pénzügyi frikciók nélküli modellben, valamint likviditási szempontból homogén bankrendszert feltételezve (likviditáshiányos pénzügyi szereplők feltételezése nélkül). Az eredmények igazolják a pénzügyi súrlódások és a pénzügyi rendszer intézményei likviditási helyzetének szerepét a válság során. Pénzügyi frikciók feltételezése nélkül a hatások enyhébbek, a visszarendeződés gyorsabb. Likviditási szempontból homogén bankrendszert feltételezve (minden bank bőségesen rendelkezik likviditással, és tevékenységéhez nem szükséges addicionális forrásgyüjtés, azaz nincs likviditási korlátja) a hatások jelentősebbek, azonban a visszarendeződés is gyorsabb. Az elemzési horizonton a sokk hatása megegyezik a bankrendszer nélküli futtatáséval. 


\section{A pénzügyi frikciók szerepe a modellben a magyar gazdaságra gyakorolt} hatás során

(GDP százalékos változása - felső ábra; beruházás százalékos változása - alsó ábra)

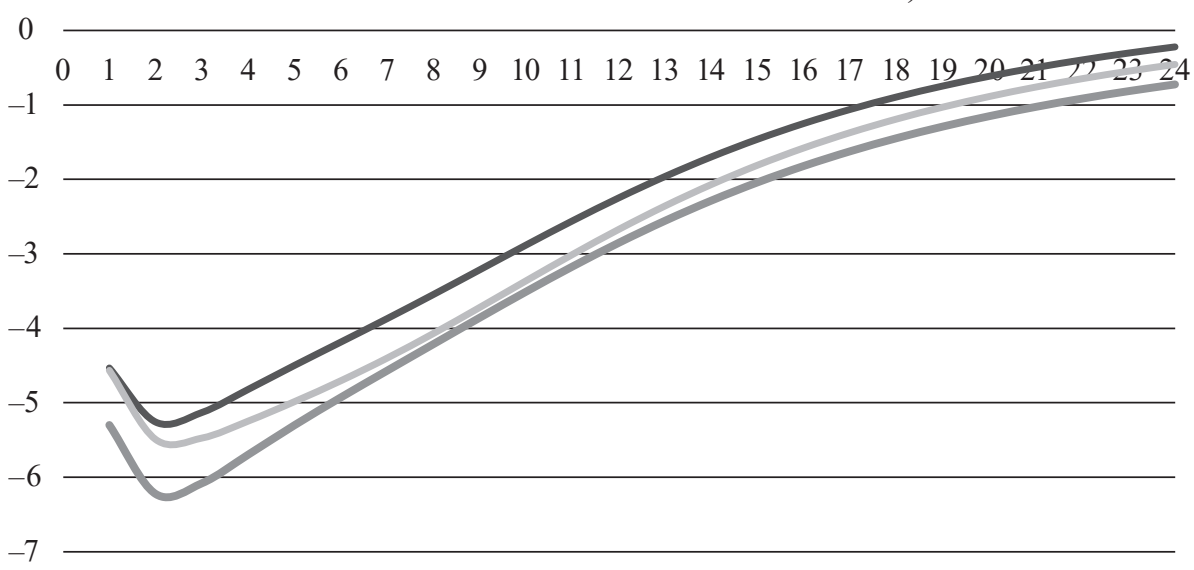

Magyar GDP (százalék) (Pénzügyi frikciók nélkül)

- Magyar GDP (százalék) (Homogén pénzügyi rendszer)

Magyar GDP (százalék) (Likviditási szempontból heterogén pénzügyi rendszer)

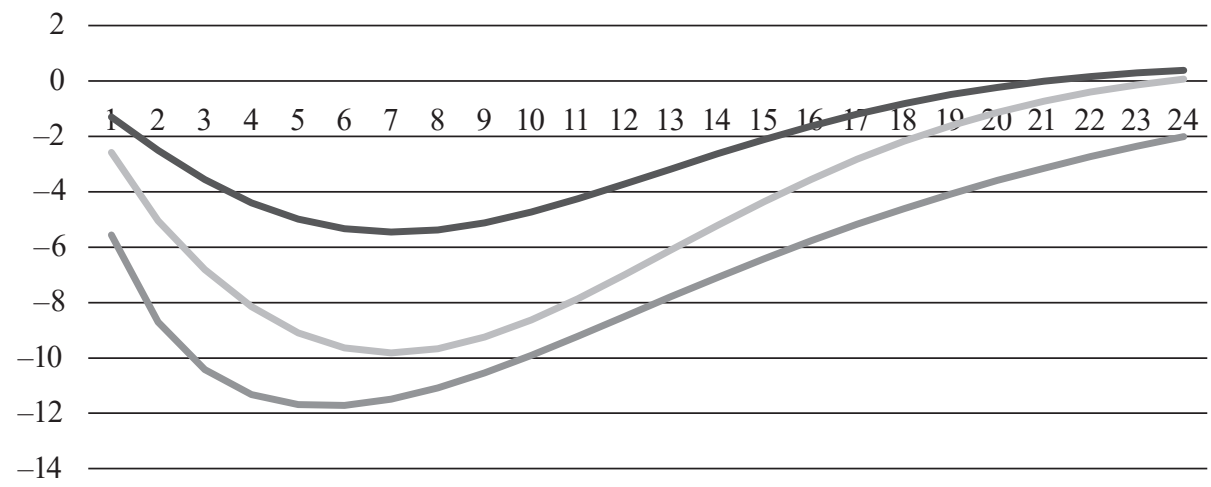

$-14$

Magyar beruházás (százalék) (Pénzügyi frikciók nélkül)

Magyar beruházás (százalék) (Homogén pénzügyi rendszer)

Magyar beruházás (százalék) (Likviditási szempontból heterogén pénzügyi rendszer)

Forrás: International Monetary Fund (2020) alapján a szerző saját számításai. 
A benchmarkszcenárión túl a pandémia hatásainak a felmérése érdekében hat további forgatókönyv eredményeit vizsgáltuk a bankrendszer állapotának függvényében.

Ezek a szcenáriók a modell szerint illikvidnek definiált bankok arányának módosításával határozhatók meg. A benchmarkforgatókönyv (BM) eredményeit már bemutattuk, a forgatókönyvtöl való eltérést a GDP alapján vizsgáltuk. E forgatókönyvekben a következő feltételezések mellett tárgyaltuk a pandémia makrogazdasági hatásait a két modellezett entitás esetében (lásd a 5. táblázatot):

- kizárólag az euróövezetben kedvezőbb a bankok likviditása (SZC1);

- kizárólag Magyarországon kedvezőbb a bankok likviditása (SZC2);

- mind az euróövezetben, mind Magyarországon kedvezőbb a bankok likviditása (SZC3);

- kizárólag az euróövezetben rosszabb a bankok likviditása (SZC4);

- kizárólag Magyarországon rosszabb a bankok likviditása (SZC5);

- mind az euróövezetben, mind Magyarországon rosszabb a bankok likviditása (SZC6).

5. táblázat

Szcenáriók definiálása: illikvid bankok aránya ${ }^{3}$

\begin{tabular}{lccccccc}
\hline & BM & SZC1 & SZC2 & SZC3 & SZC4 & SZC5 & SZC6 \\
\hline $\begin{array}{l}\text { Illikvid bankok aránya az euró- } \\
\text { övezetben (\%) }\end{array}$ & 25 & 17,5 & 25 & 17,5 & 32,5 & 25 & 32,5 \\
$\begin{array}{l}\text { Illikvid bankok aránya Magyar- } \\
\text { országon (\%) }\end{array}$ & 15 & 15 & 7,5 & 7,5 & 15 & 22,5 & 22,5 \\
\hline
\end{tabular}

Forrás: Poutineau-Vermandel (2014) alapján készült feltételezések.

Az euróövezet bankjainak kedvezőbb likviditási helyzete (SZC1) kismértékben (0,3, illetve 0,1 százalékponttal) mérsékelné az euróövezet és a magyar gazdaság visszaesését. A magyar bankok likviditásbősége természetesen érdemben nem befolyásolná az euróövezet válságreakcióját, de a magyar gazdaság visszaesését 0,2 százalékponttal fogná vissza. Ha a bankok bővebb likviditását feltételezzük mind az euróövezetben, mind Magyarországon, akkor ez 0,3-0,3 százalékponttal enyhítené a pandémiát követő recessziót. 


\section{Az euróövezet és a magyar gazdaság GDP-növekedési üteme az IMF várakozásai alapján különböző likviditásszcenáriók mentén}

(Százalék)

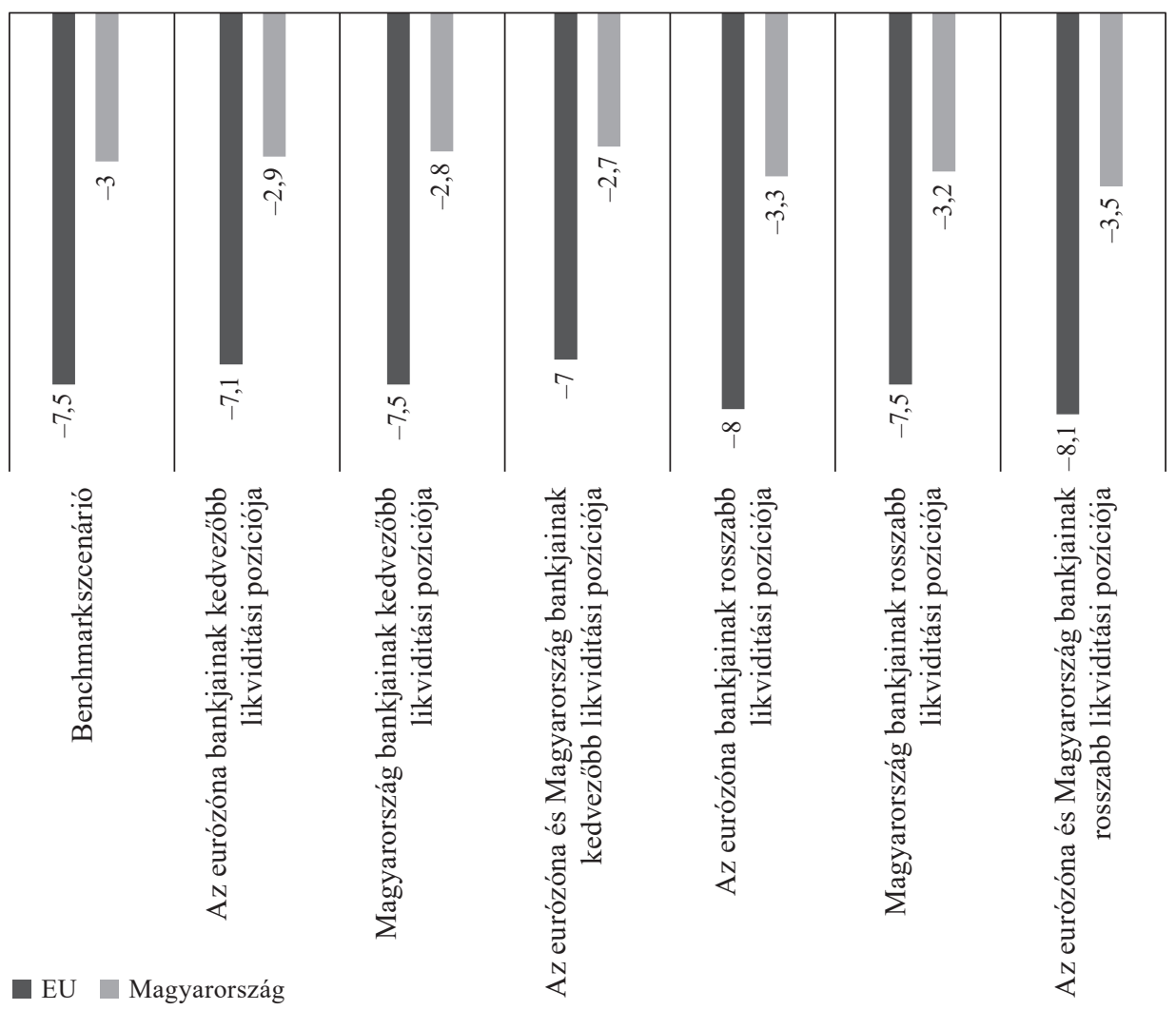

Forrás: International Monetary Fund (2020) alapján a szerző saját számításai.

Az euróövezet bankjai esetében feltételezett szükebb likviditás szignifikánsan nagyobb recessziót eredményezne mind az euróövezetben, mind Magyarországon, 0,4, illetve 0,5 százalékponttal nagyobb GDP-visszaeséssel. Ezzel szemben a kizárólag Magyarországon romló likviditás mindössze 0,3 százalékponttal nagyobb recessziót idézne elő itthon, az euróövezet változatlan mértékủ reakciója mellett. Mindkét entitás bankrendszerének gyengébb likviditása 0,4 százalékponttal növelné az euróövezet és 0,7 százalékponttal a magyar gazdaság visszaesését. 


\section{Az eredmények értékelése}

Az eredmények alapján megállapítható, hogy a magyar bankrendszer likviditásának egyenletes bővítése - amelyben szerepe van mind a monetáris politikának, mind a szabályozásnak (mikro- és makroprudenciális politika) - a hazai gazdaság stabilizálásának szükséges, de nem elégséges feltétele. A hatások ugyanis aszimmetrikusak, azaz az euróövezet bankrendszere likviditásának javulása kismértékben járul hozzá a hazai hatás csökkentéséhez, gyengülése viszont szignifikánsan erösíti a negatív hazai makrogazdasági hatásokat. A negatív hatások minimalizálásához célzott, jól időzített intézkedésekre van szükség, amelyek továbbra is - átlátható és fenntartható (minimális prudenciális elvárásokat kielégítö) tevékenység mellett - segíthetik a kilábalást. Ehhez a monetáris politika likviditásbővítéssel, a szabályozás kontraciklikus eszközök bevetésével járulhat hozzá. A likviditási és tőketartaléktöbbletek felhasználásával a bankok biztosíthatják müködésüket, átstrukturálhatják a kedvezőtlenül érintett adósok hiteleit és fenntarthatják a fizetési rendszer zökkenőmentes müködését.

Amíg a fejlett piacgazdaságokban a jegybankok jelentős része a saját fizetőeszközében bármekkora pénzteremtésre képes, addig a gazdasági szereplők számára a pénzteremtés fö forrásai a kereskedelmi bankok. A jegybank által teremtett pénz (többletlikviditás a bankrendszer számára) csak lehetőséget ad a bankok számára, hogy a reálgazdasági igényeket kielégítő pénzt teremtsenek. A bankok által biztosított pénzteremtés mértéke ugyanakkor már függ a hitelek iránti kereslettől, a finanszírozható projektek kockázatosságától, a bankok profitabilitásától és likviditási pozíciójától. Ez utóbbit enyhíti a bankrendszerbe juttatott többletlikviditás. Mivel a gazdaságban a kapacitások kihasználatlanok, a kereslet elégtelen, ezért a többletlikviditás nem közvetít inflációs nyomást, legalábbis rövid távon. Mindez indokolhatná, hogy tartósan növeljék a bankrendszer likviditását, ami azonban költséggel és kockázattal járhat. Egyrészt jelentősen ronthatja a monetáris politika transzmissziójának hatékonyságát, másrészt torzíthatja a bankok kockázatviselési toleranciáját, ami pótlólagos kockázatvállalást, ezáltal instabilitást eredményezhet. Teljes kapacitáskihasználtság esetén a többletlikviditás túlfütöttséghez, így inflációhoz és fenntarthatatlan növekedési pályához vezethet. A monetáris lazítás jelentős költségekkel is jár, ugyanakkor a csökkenő kamatlábakon keresztül mérsékli az állami kamatkiadásokat, ami azonban további eladósodásra ösztönözheti az államot. Más közgazdasági döntésekhez hasonlóan a likviditás fenntartása is számos „trade- 
off" figyelembevételével történik, ezért a monetáris politika mellett a mikro- és makroprudenciális szabályozásra is jelentős szerep hárul.

Kitekintésként elmondható, hogy a bankok megpróbálják hitelezési kapacitásaikat kihasználni és jövedelmezőségük megtartása érdekében új megoldásokat találni. Ez új és gyorsan bevezetett technológiai újítások és fintech megoldások terjedését teheti lehetővé. A pénzügyi termékek körében is új innovációkra számíthatunk, amelyek a később esetleg fellépő hasonló kockázatok fedezésére szolgálnak.

A koronavírus-járvány jellegéből adódóan a bankrendszer vélelmezhetően egyre nagyobb figyelmet fordít majd az egészségügyi beruházások és a biotechnológiai cégek finanszírozására. Az utóbbi iparág felemelkedése sok ország fejlódésében stratégiai szerepet is játszhat. A közeljövőben a bankok valószínủleg felülsúlyozzák majd e szektor vállalatait, miként ez a „zöld” projektek esetében történt. Egy ilyen váltás újrapozicionálhatja a banki szektort a társadalom szemében. Azoknak a bankoknak, amelyek kimaradnak az ilyen társadalmilag fontos területek finanszírozásából, jelentős stratégiai veszteségekkel kell szembesülniük.

Az ilyen jelentős változások időszakában a bankszabályozásnak különösen gyorsan célszerủ reagálnia és alkalmazkodnia az új banki magatartáshoz, mégpedig úgy, hogy miközben stabil és fenntartható mederben tartja a reálgazdaság szükségleteinek finanszírozását, ne gátolja a piaci folyamatokat.

\section{Összefoglalás, következtetések}

A tanulmány középpontjában a koronavírus-járvány nyomán bekövetkezett válság és az annak mértékére hatást gyakorló bankrendszeri likviditás áll. Az elemzés során részletesen bemutattuk a bankközi piac likviditásának reálgazdasági szerepét. A tanulmányban a nemzetközi tőkeáramlás és a két entitás közötti szoros gazdasági kapcsolatok miatt a magyarországi hatásokat és hatásmechanizmusokat az euróövezettel összefüggésben, a pénzügyi kapcsolatokat is tartalmazó dinamikus modellkeretben vizsgáltuk. Konkrétan arra a kérdésre kerestük a választ, hogy a bankrendszer likviditási helyzete és annak változása milyen módon és mértékben befolyásolja a koronavírus-járvány által előidézett gazdasági hatásokat. Az elemzésben alkalmazott több országot tartalmazó dinamikus modell heterogén bankokat feltételezve képes megragadni és bemutatni a bankközi piacnak és likviditásának szerepét a gazdasági sokkokra adott reakciókban. A vizsgálatban figyelembe vettük a bankközi piaci kondíciókat, a nemzetközi tőkeáramlást és a múködésüket dina- 
mikusan optimalizáló gazdasági aktorokat. Szem előtt tartva a bankok heterogenitását, a tanulmány igazolta azt a feltételezést, hogy a bankrendszer likviditásának elemzése segíthet megérteni és leírni a monetáris politika és a szabályozás közötti összefüggéseket, beleértve jelentőségüket a makrogazdasági fenntarthatóság szempontjából.

A tanulmány a hazai és a nemzetközi szakirodalomban is az elsők között tárta fel egy kis és nyitott országot, illetve nagy gazdasági egységet tartalmazó dinamikus modellben a nemzetközi tőkeáramlások szem előtt tartásával a gazdasági sokkok és a heterogén szereplőkből álló bankrendszer likviditási pozíciója közötti összefüggéseket, hatásokat, hatásmechanizmusokat és következményeket. Gazdasági sokkon a koronavírus-járvány által kiváltott negatív keresleti és kínálati sokkokat értettük, azok tovagyürüző hatásait is beleértve. A tanulmányban alkalmazott modell Poutineau és Vermandel [2014] több országot tartalmazó, de azonos monetáris övezetet feltételező modelljének általunk kibővített és továbbfejlesztett változata, amely finomítja és gazdagítja a korábbi elméleti és módszertani megközelítést. A módosítás lényeges eleme, hogy a modellben leírt egyik gazdasági egység kis és nyitott országként definiálható, amely önálló monetáris politikával bír, ugyanakkor a nagy gazdasági régióval szoros gazdasági kapcsolatokat ápol.

Az eredmények megerősítik a likviditás aszimmetrikus szerepét. Első következtetésünk szerint a válság hatásainak minimalizálásához kedvező likviditás szükséges, és a gyors visszapattanásnak is feltétele. A gyengülő likviditás viszont sokkal súlyosabb negatív következményekkel jár, mint amilyenek a bővülő likviditás pozitív hatásai. A likviditási helyzet kismértékủ romlásának is jelentős negatív következményei lehetnek, amelyek nemcsak a visszaesés mértékének árában juthatnak kifejezésre, hanem a kibocsátás tartósabb csökkenésében is. Ugyanakkor a likviditásbőség önmagában nem tudja mérsékelni a válság negatív reálgazdasági következményeit, mert az egészséges pénzügyi rendszer nem feltétlenül párosul olyan valós hitelkereslettel, amely mögött reálgazdasági motívumok húzódnak meg. Ez utóbbi esetben a várakozások szerepe kiemelkedő.

Második következtetésünk szerint a bankrendszer likviditásának bővítésén túl az egyes bankok szerepe és likviditási pozíciója is fontos a magyar gazdaság gyors talpra állításában. A hatások aszimmetrikusak, azaz az euróövezet likviditásának javulása kismértékben mérsékli a hazai válságot, romló likviditása viszont szignifikánsan fokozza a negatív hazai makrogazdasági hatásokat.

Harmadik következtetésünk kiindulópontja értelmében a jegybank által a bankközi piacon biztosított többletlikviditás lehetővé teszi a bankok számára, hogy 
többletaktivitásukkal hozzájáruljanak a reálgazdasági növekedéshez. A tényleges reálgazdasági hatás azonban már nemcsak a többletforrástól és a banki szándéktól, hanem többek között a hitelkereslettől is függ. Mivel a gazdaságban kihasználatlan kapacitások vannak és a kereslet is elégtelen, ezért a többletlikviditás rövid távon nem közvetít inflációs nyomást. Mindez indokolhatná a bankrendszer likviditásának tartós növelését, ami azonban költségekkel és kockázatokkal járhat. Egyrészt jelentősen ronthatja a monetáris politika transzmissziójának hatékonyságát, másrészt torzíthatja a bankok kockázatviselő hajlandóságát, ami pótlólagos kockázatvállaláshoz, ezáltal a pénzügyi rendszer instabilitásához vezethet. Teljes kapacitáskihasználtság esetén a többletlikviditás a gazdaság túlfütöttségét, így inflációt, ezáltal fenntarthatatlan növekedési pályát eredményez.

A monetáris lazítás jelentős költségekkel is jár, a csökkenő kamatlábszint pedig további eladósodásra ösztönözheti az államot. A bankok az ügyfelek készpénzigényének kielégítése, valamint a napi tranzakciók és a fizetési rendszer fenntartása miatt folyamatosan likviditáskeresletet generálnak. A bankrendszer likviditásbősége esetén is a többletlikviditás koncentrálódik, így megkülönböztethetők likviditásszufficites és likviditásdeficites bankok.

A válság hatásainak enyhítéséhez az átmeneti likviditásbővítésen túl a szabályozásban szükség van anticiklikus eszközök bevetésére is. A likviditási és tőketartaléktöbbletek felhasználásával a bankok biztosíthatják müködésüket, átstrukturálhatják a válság által kedvezőtlenül érintett adósok hiteleit és fenntarthatják a fizetési rendszer zökkenőmentes funkcionálását.

A hatások minimalizálásához szükségesek célzott, jól időzített intézkedések, amelyek továbbra is átlátható és fenntartható (minimális prudenciális elvárásoknak eleget tevő) tevékenység mellett segíthetik a kilábalást. A szabályozásnak közelről célszerủ figyelemmel kísérnie a folyamatokat, és gyorsan, de rugalmasan (a piaci viszonyokat nem torzítva) kell alkalmazkodnia hozzájuk.

A tanulmány olyan további kutatások alapjául szolgálhat, amelyek a monetáris politika és a pénzügyi rendszer szabályozása közötti kapcsolatot, azok egymásra gyakorolt hatását, valamint gazdaságpolitikai célok eléréséhez azok összehangolásának követelményeit tárják fel. 


\section{Hivatkozások}

Adrian, T. - Shin, S. H. [2009]: Money, liquidity and monetary policy. Federal Reserve Bank of New York, Staff Report. No. 360. DOI: 10.1257/aer.99.2.600. Letölthető: https://www.aeaweb.org/ articles?id=10.1257/aer.99.2.600

Bernanke, B. - Gertler, M. - Gilchrist, S. [1998]: The financial accelerator in a quantitative business cycle framework. NBER Working Paper, 6455. DOI: 10.3386/w6455. Letölthető: https://www. nber.org/papers/w6455

Carabenciov, I. - Ermolaev, I. - Freedman, C. - Juillard, M. - Kamenik, O. - Korshunov, D. - Laxton, D. - Laxton, J. [2008]: A small quarterly multi-country projection model. IMF Working Paper, No. 08/279. DOI: 10.5089/9781451871371.001. Letölthető: https://www.imf.org/en/Publications/WP/ Issues/2016/12/31/A-Small-Quarterly-Multi-Country-Projection-Model-22487

Cozzi, G. - Pariés, M. D. - Karadi, P. - Körner, J. - Kok, C. - Mazelis, F. - Nikolov, K. - Rancoita, E. - Van der Ghote, A. - Weber, J. [2020]: Macroprudential policy measures: Macroeconomic impact and interaction with monetary policy. ECB Technical Papers, No. 2376. DOI: 10.2866/098813. Letölthető: https://www.ecb.europa.eu/pub/pdf/scpwps/ecb.wp2376 7e9a0cae47.en.pdf

Eickmeier, S. - Kolb, B. - Prieto, E. [2018]: Macroeconomic effects of bank capital regulation. Deutsche Bundesbank Discussion Paper, No. 44/2018. Letölthető: https://ideas.repec.org/p/zbw/ bubdps/442018.html

Európai Bizottság [2017]: The Global Multi-country model (GM): And Estimated DSGE model for the Euro Area countries. JRC Working Papers in Economics and Finance, 2017/10.

European Commission [2020]: European Commission Forecast Spring 2020. Institutional Paper 125, May. DOI: 10.2765/254908. Letölthetö: https://ec.europa.eu/info/publications/global-multicountry-model-gm-estimated-dsge-model-euro-area-countries_en

Fender, I. - Lewrick, U. [2016]: Adding it all up: The macroeconomic impact of Basel III and outstanding reform issues. BIS Working Papers, No. 591. Letölthető: https://ideas.repec.org/p/bis/ biswps/591.html

Gali, J. [2007]: Monetary policy, inflation and the business cycle: An introduction to the new keynesian framework and its applications. Princeton University Press.

Gerali, A. - Neri, S. - Sessa, L. - Signoretti, M. F. [2010]: Credit and banking in a DSGE model of the euro area. Journal of Money, Credit and Banking, Vol. 42., 107-141. o. DOI: 10.2139/ssrn.1601937. Letölthetö: https://papers.ssrn.com/sol3/papers.cfm?abstract_id=1601937

Gertler, M. - Karádi, P. [2011]: A model of unconventional monetary policy. Journal of Monetary Economics, Vol. 58., No. 1., 17-34. o. https://doi.org/10.1016/j.jmoneco.2010.10.004. Letölthetö: https://ideas.repec.org/a/eee/moneco/v58y2011ilp17-34.html

Iacoviello, M. [2005]: House prices, borrowing constraints and monetary policy in the business cycle. American Economic Review, Vol. 95., No.3., 739-764. o. DOI: 10.1257/0002828054201477. Letölthetö: https://www.aeaweb.org/articles?id=10.1257/0002828054201477

International Monetary Fund [2020]: World Economic Outlook, April. Letölthető: https://www.imf. org/en/Publications/WEO

Jylha, P. [2016]: Does funding liquidity cause market liquidity? Evidence from a Quasy-Experiment. Working Paper at Aalto University. Letölthetö: https://papers.ssrn.com/sol3/papers.cfm?abstract_ id $=2651088$

Kolozsi Péter - Horváth Gábor [2020]: Mennyit ér a likviditás? A magyar bankrendszer likviditáskeresleti függvényének becslése. Közgazdasági Szemle, LXVII. évf. DOI: http://dx.doi. org/10.18414/KSZ.2020.2.113. Letölthető: http://real.mtak.hu/106249/1/01KolozsiHorvathA.pdf

Kutatóintézetek [2020]: Konjunktúraelemzések 2020 tavaszán. Külgazdaság, LXIV. évf., márciusáprilis, 3-44. o. 
Poutineau, J. C. - Vermandel, G. [2014]: Cross-border banking flows spillovers in the eurozone: Evidence from an estimated DSGE model. Journal of Economic Dynamics and Control, Vol 51., 378-403. o. DOI: https://doi.org/10.1016/j.jedc.2014.11.006. Letölthető: https://papers.ssrn.com/ sol3/papers.cfm?abstract_id $=2665578$

Váradi Kata [2012]: Volt-e likviditási válság - Volatilitás és likviditás kapcsolatának vizsgálata. Hitelintézeti Szemle, 11. (k)sz., 69-78. o. Letölthető: http://unipub.lib.uni-corvinus.hu/1036/1/6978-ig-varadi-kata.pdf 